\title{
Students' Commitment to National Heritage, Patriotism and Nationalism (The Case of Indonesian Elementary Students in Border Area with East Timor)
}

\author{
L. Hendrowibowo 1)*, Yohanes Harsoyo ${ }^{2)}$, ${ }^{3)}$ Sunarso \\ 1), 3) Universitas Negeri Yogyakarta, Indonesia \\ 2) Universitas Sanata Dharma, Indonesia \\ *Correspondence Author, hendrowibowo@uny.ac.id
}

\begin{abstract}
This study aims to describe the commitment to national heritage, patriotism, nationalism of elementary school students in the border areas between Indonesia and Timor Leste. This research was conducted in three elementary schools, they are SD Inpres Moto Ain, SD Inpres Class Jau Halimuti, SD Kristen Nanaeklot, and SD Negeri Motabenar from June to August 2018. The subjects of this study were elementary students in the IndonesiaTimor Leste border areas precisely around Motaain City, Belu Regency, East Nusa Tenggara. The research questionnaire was adapted from Karazawa and analyzed with descripriptive statistics. The results of this study showed that the commitment to national heritage, patriotism, and nationalism of elementary students on the Indonesian border areas with Timor Leste is in the very high level.
\end{abstract}

Keywords: Commitment to national, Heritage, Patriotism, Nationalism.

\section{Introduction}

Indonesia is a unique country with its diversity based on ethnicity, religions, cultures, and local languages. Almost half of the people are Javanese $(40.1 \%)$, while others are Sundanese 15.5\%, Malay 3.7\%, Batak 3.6\%, Madurese 3\%, Betawi 2.9\%, Minangkabau $2.7 \%$, Buginese $2.7 \%$, Bantenese 2\%, Banjarese 1.7\%, Balinese 1.7\%, Acehnese 1.4\%, Dayak $1.4 \%$, Sasak 1.3\%, Chinese 1.2\%, other 15\% (2010 est.)[1] (Tucci, 2016). Despite this diversity, Indonesia has committed to peacefully live together based on Bhinneka Tunggal $I k a[2]$, a national jargon that comes from the Sanskrit language which means diversity in unity. This has actualized national insight that refers to geographical constellations, sociocultural conditions, historical factors, and environmental developments. The diversity includes a geographical area with various natural resources (flora, fauna, mineral, and natural gas) and ethnicity living from Sabang to Merauke. In addition, Indonesia is rich in religions, social-cultural aspects, and languages. This diversity is the mosaic that shapes a united Indonesia. Therefore, understanding Indonesia means to understand its united diversity mosaic.

A long time ago, Soekarno, the first President of Indonesia, had reminded people that "Indonesia is not a for-one-person country nor a for-one-group country, yet Indonesia is a forall country: one for all, all for one [3].The nation founders aimed this country with the principles of cooperation, togetherness, and eliminating group selfishness. However, there is a worrisome that the national insight of Indonesians starts fading away since the eighties [4]. The emergence of ethnic, religious, racial, and class sentiments that often encourage friction or conflicts is an indication of nationalism decline. The deviated interpretations of Pancasila as the basic ideology of Indonesia also emerged as a threat to nationalism strength. If the nation ignores to take care of the cases, then the arisen problems may threaten the national peaceful living and create the nation's disintegration.

Considering the above situations, students need to get character or personality education from an early age. Through the good-characters human beings, they can realize the ideals of national life. It is not an easy task because there have been great changes in each nation as the consequences of technology development which produces a new human-being 
generation [5]. In this situation, teachers should make continuous efforts in adopting the technology development. For example, Lee's research [6] in Korea explored how early childhood education programs both in school and in the home ensures children's positive character education in order to prevent them from the intervention of foreign culture via technology. Character education balances the tendency of materialism and selfishness that considered as "an academic success" nowadays. With character education, educators enables more to promote care, the pride of cultural heritage, and respect for cultural diversity as well as cooperation [7].

The research aims to describe the commitment to national heritage, patriotism, and nationalism of elementary students in Belu Regency, East Nusa Tenggara. Belu Regency is in the border areas between Indonesia and Timor Leste. As located far away from the central government, local development in this area is generally more left behind than other areas in Indonesia. Some research revealed that Indonesian children, especially in Belu, almost do not play traditional games considering that Belu Regency is on Timor Island that is still rich with its cultural values. The cause of the declining existence of traditional games is the emergence of new and modern games that are more popular with children. On the other words, the children' commitment to national heritage is decreasing. On the other side, the togetherness built by the nation's founders has faced a more challenging reality of morality and nationalism values decrement, national identity negligence, more ethnics, races, and religious conflicts, and the raising of national disintegration issue [8].

\section{Students' Commitment to National Heritage}

A commitment related to national or cultural heritage is a serious promise made by a person (to the counselor, to "nears and dears", to reality, to "God", etc.) to reject the stereotypes and patterns of behavior which have been installed by the particular oppressions operating in that person's nation or culture. Heritage is our legacy from the past, what we live with today, and what we pass on to future [9].

National Heritage Areas are places where natural, cultural, historic, and scenic resources combine to form a cohesive, nationally important landscape arising from patterns of human activity shaped by geography [10].

Managed locally, National Heritage Areas play a vital role in preserving the physical character, memories, and stories of our country, reminding us of our national origins and destiny. This is a citizens' movement of high purpose and great benefit to the nation [11].

\section{Nationalism among Indonesian Students}

Nationalism is the terminology often used in political science. It is also often associated with national histories. The history of Indonesian independence after struggling against colonialism clearly shows that people love their country to be free from colonials [12]. People's spirit to love their own country has exceeded their love to their own ethnic, culture, religion, and any other differentiators. Nationalism unites the desires to live together as a national community that aims the same goals and objectives. Nationalism becomes the unifying tool for nation-forming elements as well as an ideology to place love, loyalty, and commitment to country and nation [13]. Nationality for Indonesia refers to unify various ethnics in one bowl named The Unitary State of the Republic of Indonesia. In this concept, the unity refers to its unified Indonesian netizens, later called as Indonesia nationalism. As Indonesia netizens hold Pancasila as their national ideology, thus Indonesia nationalism can also be called as Pancasila nationalism; nation understanding that is based on Pancasila values [14]

However, a nation lives with other nations. This state has both positive and negative effects. One of its negative effects of association between nations is the waning of people's love to their own nation on various aspects or nationalism. The tendency of individualism and copycat to other nation's cultures which is different from own norms, the tendency to 
purchase overseas products compared to domestic products, the tendency to speak foreign language compared to national language are the examples that the love to own country has been diminishing. One of the determinant factors of nationalism and patriotism spirits decrement is the rapid development of science and technology contributing to the entry of foreign values and cultures into Indonesia [15]. Nonetheless, students' way of thinking is often based on what is seen and felt, without screening which values and cultures is suitable with own values and cultures. This causes them reluctant to show their nationalism and patriotism in everyday life.

\section{Patriotism for Indonesian Students}

Patriotism idea has a noble moral content. Patriotism refers to defensive attitude; the heroic action while the nation is being attacked [16]. Patriotism shows a country's people readiness to die for their country [17], while nationalism precisely depicts those who are involved in aggressive expansionist politics. Both patriotism and nationalism are two sides of a same coin. The dichotomies of them is often misleading; on one side, these cover each other yet on the other side, these dichotomies are most of it coincides [18]. From etymology side, patriotism is derived from word "patria" which means country of the father [16]. For many writers, the idea of patriotism marks the transition of patria and nation: patriotism is imbued with devoted loyalty to the king, and the latter people build their social sides and values themselves for the nation's sake. In this terminology, this patriotism definition reminds the relationship between nation and nationalism [16].

There are too many comparative and theoretic books that deal with nation and nationalism simultaneously. Nationalism is an ideology that often claims the control of a nation and/or promotes its superior identity over others. Therefore, there are some similarities between nationalism theories and other ethnicity theories compared to nation and nationalism theories [16].

Patriotism is soul and spirits to love the homeland completing the existence of nationalism [14]. Patriotism shows one's willingness to sacrifice anything for the sake of his nation's glory and prosperity. Indonesians needs to unify, love the nation passionately, and sacrifice anything to defend the country as an independent country. On other words, patriotism is a part of nation understanding in Indonesia's nationalism [14].

Patriotism includes proud attitude towards own achievements, cultures, and willingness to preserve national characteristics and its background. Rashid [19] mentioned some patriotism values: loyalty, bravery, and love for the nation and country. Patriotism education is a lifetime process because the nation's sovereignty threats are not static and can be in the any forms of threat: economy, culture, and military. Patriotism spirit has to be added from time to time consistently so that the spirit will be fading away and vanished [20]

\section{Materials \& Methods}

This piece of research implemented quantitative and qualitative methods (mixed methods). The subject of the research was elementary students in the border areas between Indonesia and Timor Leste; in Motaain City, Belu Regency, East Nusa Tenggara. The number of samples was determined proportionally based on the numbers of elementary students in each sampling area. The total sampling was 52 elementary students. The chosen elementary schools were Inpres Moto Ain Elementary School, Inpres Kelas Jau Halimuti Elementary School, K Nanaeklot Elementary School, and Motabenar State Elementary School.

The research was conducted starting from June to August 2018. Data gathering used was questionnaires. The research questionnaires adapted questionnaires used by Karasawa [21]. Statistic descriptive was used as data analysis techniques. Variable of commitment to national heritage consists of 5 question items; variables of patriotism and nationalism consist of 6 question items respectively. Each item consists of 6 options ranging from strongly agree (score 6) to strongly disagree (score 1).

\section{Results and Discussion}


The number of respondents in this research was 52 elementary students in border areas between Indonesia and Timor Leste; in Motaain City, Belu Regency, East Nusa Tenggara. Most of students' parents' occupation were farmers (78.85\%), and the rest of them were fishermen $(9.62 \%)$, contractors $(3.85 \%)$, private employees $(3.85 \%)$, teachers $(1.92 \%)$, and drivers $(1.92 \%)$. The students were mostly in the fifth grade $(61.5 \%)$, and the others were in the second grade $(26.9 \%)$ and in the fourth grade $(11.5 \%)$. The male students were $53.8 \%$ and the female students were $46.2 \%$ who became the research respondents. See Table 1.

Table 1: Respondents' identity

Source: Primary data

\begin{tabular}{cccc}
\hline Identity & Information & $\begin{array}{c}\text { Frequ } \\
\text { ency }\end{array}$ & Percentage \\
\hline $\begin{array}{l}\text { Parents' } \\
\text { Occupati } \\
\text { on }\end{array}$ & Farmer & 41 & $78.84 \%$ \\
& & & \\
& Fisherman & 5 & $9.62 \%$ \\
& Contractor & 2 & $3.85 \%$ \\
& Private & 2 & $3.85 \%$ \\
& Employee & & \\
& Teacher & 1 & $1.92 \%$ \\
& Driver & 1 & $1.92 \%$ \\
\hline Grades & & 52 & $100 \%$ \\
\hline & 2 & 14 & $26.9 \%$ \\
& 5 & 6 & $11.5 \%$ \\
\hline Gender & Male & 52 & $61.5 \%$ \\
\hline & Female & 28 & $100 \%$ \\
\hline & & 52 & $53.8 \%$ \\
& & & $46.2 \%$ \\
\hline
\end{tabular}

The general description of students' commitment to national heritage shows the average of 24,154 with theoretical range of 5-25. This shows students have high commitment to the state symbol. Students' patriotism shows the average of 27,865 with theoretical range of 6-30. This state shows that students have very high patriotism to Indonesia. Meanwhile, students' nationalism shows the average of 25,596 with theoretical range of 6-30. This state also shows that students have high nationalism. See table 2.

Table 2: Commitment to national heritage, patriotism, and nationalism

\begin{tabular}{lccrr}
\hline Variable & $\begin{array}{c}\text { Actual } \\
\text { Range }\end{array}$ & $\begin{array}{c}\text { Theoretic } \\
\text { al } \\
\text { Range }\end{array}$ & Mean & $\begin{array}{r}\text { Deviat } \\
\text { ion } \\
\text { Stand } \\
\text { ard }\end{array}$ \\
\hline Commitment & $19-25$ & $5-25$ & 24,154 & 1,539 \\
Patriotisme & $22-30$ & $6-30$ & 27,865 & 2,612
\end{tabular}




\begin{tabular}{lllll} 
Nasionalisme & $17-30$ & $6-30$ & 25,596 & 3,663 \\
\hline
\end{tabular}

Below is the description of indicators for the commitment to national heritage, patriotism, and nationalism (see Table 3).

Table 3: The indicators sequence for commitment variable to national heritage, patriotism and nationalism

\begin{tabular}{ll}
\hline Variable & Indicators \\
\hline (1) Commitment to & (1) I feel excited every time I hear the national anthem, \\
National Heritage & Indonesia Raya (4.94); \\
& (2) The most important feeling is the love to Indonesia (4.85); \\
(3) The original Indonesian children's games must be preserved \\
(4) I am proud every time I see the national flag Sang Saka \\
(5) Sang Saka Merah Puth is the most fascinating national flag \\
(2) Patriotism \\
(1) I love my country, Indonesia (4.87); \\
(2) I am proud to be an Indonesian (4.79); \\
(3) If I were reborn, I would keep being an Indonesian (4.75); \\
(4) I prefer Indonesia's domestic products to overseas products \\
(5) Indonesia is the best country in the world (4.69). \\
(6) I do not want to stay overseas (4.06). \\
(1) Indonesians are the kindest human being in the world \\
(2) Indonesia must be an example for other countries (4.69); \\
(3) Indonesia has many things to be learn by other countries \\
(4) Indonesia must open vacancy as wide as possible for foreign \\
(5) Overseas products are not as good as Indonesian products \\
(6) We must learn foreign cultures (3.85).
\end{tabular}

The research result shows that, first, commitment to national heritage of the elementary students in the border areas between Indonesia and Timor Leste was generally categorized as high. In sequence, commitment indicators to national heritage that supports the results are as follow: students are excited every time they hear the national anthem, Indonesia Raya; the most important feeling is love feeling to Indonesia; the original Indonesian children's games must be preserved; students are proud every time they see the national flag, Sang Saka Merah Putih is fluttering; and they think that Sang Saka Merah Putih is the most fascinating national flag. Second, this research result shows that patriotism of the elementary students in the border areas between Indonesia and Timor Leste was generally categorized as very high. In sequence, patriotism that supports the results is as follow: they love Indonesia; they are proud to be Indonesians; they still want to be an Indonesian if they were reborn; they like to buy Indonesian products rather than overseas products; they think that Indonesia is the best country in the world; they do not want to stay overseas. Third, this research result shows that nationalism of the elementary students in the border areas between Indonesia and Timor Leste was generally categorized as very high. In sequence, nationalism that supports the results is as follow: they think that Indonesians are the kindest human being in the world; Indonesia must be the example for other countries; Indonesia has many things to be learned by other countries; Indonesia must not open vacancies as wide as possible for foreign workers; 
overseas products are not as good as Indonesian products; they do not need to learn foreign cultures.

When elementary students in the border areas between Indonesia and Timor Leste, they were give a question: Why do they want to preserve the national heritage? The following are some of the students' answers:

"... Indonesia has the cultural, ethnics, and religions diversity so that we can be living harmoniously"

"... Even though each island has its own ethnic language, the people can get along well with the other people from other ethnicities because we are unified by national language, Bahasa Indonesia"

When elementary students in the border areas between Indonesia and Timor Leste, they were give a question: Why do they want to defend Indonesia from any threats? The following are some of the students' answers:

“... Indonesia is rich of its natural resources, like marine products, mining, spices, plantations, and cultures that often become the target of other nations."

"... Despite our insufficient conditions, we are happy because the relationship between citizens is closely intertwined. Such family-like relationship will not be found in other countries so that they ever dream to move to Indonesia..."

When elementary students in the border areas between Indonesia and Timor Leste, they were give a question: Why do they love Indonesia? The following are some of the students' answers:

“... This nation is very rich of local cultures. Many foreigners want to learn Indonesian cultures"

"... Indonesia is a harmonious nation so that other nations often imitate us"

"... There are so many traditional games so that we do not need to buy it".

\section{Conclusion \& Suggestion}

This piece of research has showed that the commitment to natural heritage of elementary students who live in border areas between Indonesia and Timor Leste is generally categorized very high; patriotism of elementary students who live in border areas between Indonesia and Timor Leste is generally categorized very high, and nationalism of elementary students who live in border areas between Indonesia and Timor Leste is also generally categorized very high.

These findings were surely an encouraging result. Although the elementary students who live in border areas between Indonesia and Timor Leste are less facilitated with both facilities and infrastructures, they still have high and strong commitment to national heritage, patriotism, and nationalism. These states absolutely need to be maintained by giving more attention to the students to access their education, developing character education at schools, and developing traditional games, etc.

\section{References}

[1] Tucci, P. A., (2016). The Handy Geography Answer Book (The Handy Answer Book Series) Third Edition. Michigan: Visible Ink Press.

[2] Hartawan, B. (2003). Unity in diversity: An indonesian vision of international relations. Strategy Research Project. U.S. Army War College Carlisle Barracks, Pennsylvania 17013. Dari: http://www.dtic.mil/dtic/tr/fulltext/u2/a559978.pdf.

[3] Adams, C. (1968). Soekarno: An Autobiography. Jakarta: Gunung Agung.

[4] Sulistiyono, S.T. (2018). The Importance of Indonesia's Nationalism Revitalization in the Globalization Era: A Historical Perspective. Journal of Maritime Studies and National Integration, 2 (1), 1-15

[5] Naisbitt, J., Naisbitt, N. \& Philips, D. (2001). High tech, high touch: Technology and our accelerated search for meaning. Nicholas Brearly, London. 
[6] Lee, G. L. (2013). Re-emphasizing character education in early childhood programs: Korean children's experiences, Childhood Education, 89(5), 315-322.

[7] Morris, R.C., and Mims, N. G. (1999). Making Classrooms Culturally Sensitive. Education and Culture. 16 (1): 29-32

[8] Azra, A. (2002). Paradigma baru pendidikan nasional rekonstruksi dan demokratisasi. Jakarta: Kompas.

[9] Adie, B. A. (2017). Franchising our heritage: The UNESCO world heritage brand. Tourism Management Perspectives, 24, 48-53. https://doi.org/10.1016/j.tmp.2017.07.002.

[10] Crang, M., \& Tolia-Kelly, D. P. (2010). Nation, race, and affect: senses and sensibilities at national heritage sites. Environment and planning A,42(10), 23152331.https://doi.org/10.1068/a4346

[11] Zhang, R., \& Smith, L. (2019). Bonding and dissonance: Rethinking the interrelations among stakeholders in heritage tourism. Tourism Management, 74, 212223.https://doi.org/10.1016/j.tourman.2019.03.004.

[12] Kusumawardhani, A. \& Faturochman. (2004). Nasionalisme. Buletin Psikologi, 12(6172).

[13] Khon, H. (1961). Nasionalisme arti dan sejarahnya. Jakarta: Pustaka Sarjana.

[14] Bakry, N. S. (2010). Pendidikan kewarganegaraan. Yogyakarta: Pustaka Pelajar.

[15] Rawantika, N.I., \& Arsana, I.M. (2013). Penanaman nilai nasionalisme dan patriotisme untuk mewujudkan pendidikan karakter pada mata pelajaran pendidikan kewarganegaraan siswa kelas X SMA Negeri 4 Sidoarjo. Kajian Moral dan Kewarganegaraan, 1(1), 39-54.

[16] Jaffrelot, C. (2003). For a theory of nationalism. Dari: https://hal-sciencespo.archivesouvertes.fr/hal-01065058.

[17] Appadurai, A. (1993). Patriotism and its futures. Public culture, 5(3), 411-429.

[18] Ignatieff, M. (1999). Benign nationalism? The possibilities of the civic ideal. Dalam E. Mortimer (ed.), People, nation and state, London, I.B. Tauris.

[19] Rashid, A.R. A.R. (2004). Patriotisme: Agenda pembinaan bangsa. Kuala Lumpur: Utusan Publications.

[20] Samsu, K.H.K, Nor, M.H.M. (2011). Kepentingan pendidikan patriotisme terhadap warganegara malaysia (the importance of patriotic education for malaysian citizens). Jati Journal of Southeast Asian Studies, 16(23-34).

[21] Karasawa, M. (2002). Patriotism, nationalism, and internationalism among Japanese citizens: An etic-emic approach. Political Psychology, 23 (4), 645-666. https://doi.org/10.1111/0162-895X.00302. 